\title{
Oligopolistic Interdependency in a Mixed Market
}

\author{
Tay-Cheng $\mathrm{Ma}^{1}$ \\ ${ }^{1}$ National Kaohsiung University of Applied Sciences, Taiwan
}

\begin{abstract}
This paper uses data from Taiwan's banking sector to investigate if state-owned banks can serve as an internal regulation mechanism to sustain market competition. In contrast to the traditional second-best literature, the evidence shows that a certain degree of market coordination exists in the industry, even if the government owns most of the dominant banks in Taiwan.
\end{abstract}

\section{Introduction}

Many studies focusing on the issue of banking market competition in the empirical literature are based on data from the United States, United Kingdom, and Canada. As opposed to the Anglo-Saxon financial system founded on private ownership of banks, in most developing countries, the state owns the majority of the banks and controls a significant portion of the financial system's assets. ${ }^{1}$ However, not too much attention has been given to the effect of such ownership settings on market competition in both the public economics and industrial organization literature. This article aims to provide an empirical study to detect the differences in competitive behaviors between state-owned banks and private banks.

Aspects of the second-best literature ${ }^{2}$ propose that state-owned banks could be instructed to maximize social welfare and could serve as a policy instrument for the government to regulate an imperfect competitive market. Thus, state-owned banks tend to provide loans at lower interest rates.

However, a criticism often made of public ownership is that the monitoring system is too poor, leaving managers with considerable discretion to pursue their personal agendas. The personal agenda could consist of a variety of elements. One of them is to avoid the stiff competition

\footnotetext{
${ }^{1}$ According to Beck et al. (1999), state-owned bank assets constitute over $70 \%$ of commercial bank assets in low-income countries, and their share is around $40 \%$ in middle-income countries.

2 See the survey of Barros and Modesto (1999).
}

from their competitors so as to make the management easier and enterprise performances superior. Vickers and Yarrow (1991) indicate that managers of state-owned enterprises are typically responsible to political decision makers, who might not be very concerned about the social welfare objective of public firms and lack strong incentives to monitor enterprise management. However, some enterprise performances (like plant closures) tend to be very sensitive politically, and may become a priority item on political agendas. Therefore, the effective discipline on public enterprises' managers arises from the threat of bankruptcy. Managers of public firms must struggle to avoid stiff market competition, and in such a situation, market coordination might exist in a mixed oligopoly industry. For instance, Connor (2004) indicates that some cartels are organized by state agencies or government-owned corporations. Azzam and Anderson (2002) also use data from the Swedish beef industry and find that the hypothesis of price-taking behavior is rejected for public firms, but not for private firms. Therefore, it is competition rather than ownership per se that is the key to efficiency.

In order to further our understanding on these oligopolistic interactions between public and private firms, this article utilizes data from Taiwan's commercial banking sector to test if state-owned banks behave such a way as to discipline the industry and provide the optimal quantity of loans, which is what the second-best models assume. If the evidence shows that a certain degree of market coordination exists among state-owned banks and private banks, then state-owned banks might not be used as a regulatory intervention in the banking market to maximize social welfare.

The main advantage of Taiwan's banking dataset is that it includes all the banks in the sector. This is of great importance especially when analyzing the type of 
ownership and its effect on market competition. The industry consists of state-owned and private banks. The two groups have different legal status, but banking products tend to be homogeneous within the network of each bank. These banks can thus be considered to be operating in the same deposit and loan market.

As to the market structure, Taiwan's banking sector contains 51 commercial banks, the leading eight firms account for $51 \%$ of the industry's outstanding loans. The sizes of state-owned banks are much larger than private banks. The former group consists of 11 banks with average assets of 21 billion USD. The latter contains 40 banks with average assets of 4.5 billion USD.

\section{The Model}

The empirical study is conducted under the structure of Spiller and Favaro (1984), and assumes that banks compete in market share by changing the quantity of loans supplied and deposits solicited. Consider a banking sector with $n$ banks producing a homogeneous output and facing a demand function given by $P_{t}=P\left(Q_{t}\right)=P\left(\sum_{i=1}^{n} q_{i t}\right)$, where $P_{t}$ is the price, $Q_{t}$ is the total quantity, and $q_{i t}$ is the $i$ th bank's output at time $t$. Each bank attempts to maximize profits $\pi_{i t}=P_{t} q_{i t}-C\left(q_{i t}\right)$, where $C\left(q_{i t}\right)$ is the total cost for bank $i$, and $M C_{i t}$ is the marginal cost. The model assumes that a firm's conjecture about rivals' reactions depends on the relative size of the firm under consideration. This requires the transformation of the conjecture to the following elasticity form:

$$
\frac{\partial q_{j t}}{\partial q_{i t}} \frac{q_{i t}}{q_{j t}}=\lambda_{j i}+\delta_{j i} m_{i t},
$$

where $\lambda_{j i}$ and $\delta_{j i}$ are constant across time, and $m_{i t}=q_{i t} / Q_{t}$ is bank $i$ 's market share. A bank's conjecture regarding its rival's reaction depends on its size as well as the groups to which it and its rivals belong. Thus, one obtains:

$\lambda_{s s}+\delta_{s s} m_{i t}, \quad \lambda_{p s}+\delta_{p s} m_{i t}, \lambda_{p p}+\delta_{p p} m_{i t}, \lambda_{s p}+\delta_{s p} m_{i t},(1)$ where subscripts $s$ (state-owned) and $p$ (private) represent the group to which the bank belongs. For instance, $\lambda_{s s}+\delta_{s s} m_{i t}$ is the conjecture of a state-owned bank $i$ concerns about another state-owned bank's reaction, and $\lambda_{p s}+\delta_{p s} m_{i t}$ is its conjecture about a private bank's reaction. After some manipulations the supply relationship for the group of state-owned banks becomes:

$$
\begin{aligned}
\sum_{i \in S} \frac{M C_{i t}}{P_{t}} \frac{m_{i t}}{M_{s t}} & =1+\frac{1}{\varepsilon}\left[M_{s t} H_{s t}+\lambda_{s s} M_{s t}-\lambda_{s s} M_{s t} H_{s t}+\delta_{s s} M_{s t}^{2} H_{s t}\right. \\
+ & \left.\lambda_{p s}\left(1-M_{s t}\right)-\delta_{s s} \sum_{i \in S} \frac{m_{i t}^{3}}{M_{s t}}+\delta_{p s} H_{s t} M_{s t}\left(1-M_{s t}\right)\right] \quad \text { whe } \\
& \text { for } i \in S,
\end{aligned}
$$

re $M_{s t}=\sum_{i \in S} m_{i t}, H_{s t}=\sum_{i \in S}\left(m_{i t} / M_{s t}\right)^{2}$, and $\varepsilon=\partial Q / \partial P / Q$ is demand elasticity. In the similar way, one can get the supply relation for the group of private banks:

$$
\begin{aligned}
\sum_{i \in P} \frac{M C_{i t}}{P_{t}} \frac{m_{i t}}{M_{p t}}=1 & +\frac{1}{\varepsilon}\left[M_{p t} H_{p t}+\lambda_{p p} M_{p t}-\lambda_{p p} M_{p t} H_{p t}+\delta_{p p} M_{p t}^{2} H_{p t}\right. \\
& \left.+\lambda_{s p}\left(1-M_{p t}\right)-\delta_{p p} \sum_{i \in P} \frac{m_{i t}^{3}}{M_{p t}}+\delta_{s p} H_{p t} M_{p t}\left(1-M_{p t}\right)\right] \text { Bes }
\end{aligned}
$$$$
\text { for } i \in P \text {, }
$$

ides, the following demand relationship is estimated using time series data for the same period:

$$
\log Q_{t}=\alpha+\varepsilon \log P_{t}+\gamma \log \left(G N P_{t}\right)
$$

where GNP is gross national product in fixed prices, $\alpha$ is the constant term, and $\gamma$ is the income elasticity of demand. The model includes two supply equations ((2) and (3)) and one demand equation (4), with only $\varepsilon$ being a common parameter. Each supply relation contains five parameters and five linearly independent regressors. To avoid simultaneity bias caused by the endogeneity, I estimate the model using the Generalized Method of Moments (GMM). The sample used to estimate the regression models covers the monthly data of 51 domestic commercial banks in Taiwan for the period 1999:7 through 2004:12. All data are obtained from the data bank of Taiwan Economic Journal.

The second-best literature worries that private firms might behave non-competitively, leading to a market failure. These studies suggest that the first best allocation can be achieved if public firms can compute the competitive price in the industry and make up any difference between the 
corresponding output and private firms' output. Hence, state-owned banks should not behave less aggressively i.e. a smaller output and higher price, for the sake of expected retaliation from their rivals.

If our empirical evidence shows that state-owned banks behave less aggressively and choose a smaller output as well as higher price, then one can claim that the second-best solution is not acceptable in Taiwan's banking sector.

\section{Empirical Results}

Cournot Conjectures. Table 1 presents the results of estimating equations (2), (3), and (4). The Cournot conjecture that a bank makes production decisions without taking account of its rivals' potential reactions, $\lambda_{s s}=\lambda_{p p}=\lambda_{p s}=\lambda_{s p}=\delta_{s s}=\delta_{p p}=\delta_{p s}=\delta_{s p}=0$,

is performed using the likelihood ratio test, and the null hypothesis is rejected at the $99 \%$ level. Thus, one can conclude that, at least, some banks do incorporate into their decision process their rivals' expected reactions.

Table 1. Estimated Coefficients of the Conjectural Elasticity Model

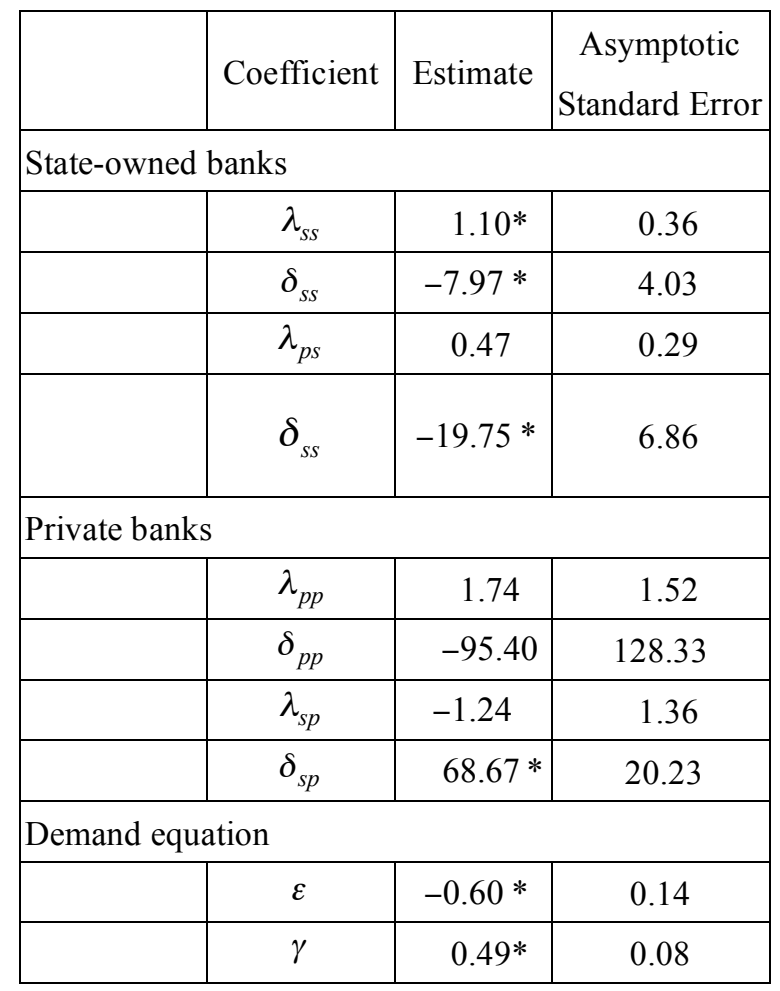

Notes: $*$ denotes that the estimate is significant at the level of $1 \%$.

Homogeneous Expectations. I next test the restriction that the conjectures are the same across two groups. The joint hypothesis becomes $\lambda_{s s}=\lambda_{p p}, \lambda_{p s}=\lambda_{s p}$, $\delta_{s s}=\delta_{p p}$, and $\delta_{p s}=\delta_{s p}$. The analogue of the likelihood ratio test is 37.98 and the hypothesis that all the parameters are the same across two groups is rejected at the $99 \%$ level. This result indicates that differences exist in conjecture patterns between state-owned banks and private banks.

Firm Interdependency. New Empirical Industrial Organization (NEIO) School argues that a firm's conjectures about its rivals' reactions are modeled in terms of the firm's position in the size distribution. Thus, a firm in the dominant group would expect strong retaliations from other dominant firms if it expands output. On the other hand, a dominant firm expects fringe firms to reduce their output when it expands its output. This belief is based on the grounds that output expansion by a dominant firm might lower prices, all else being equal, and this should lead to an output reduction by fringe firms. Firms in the dominant group do not worry about retaliations from fringe firms, since their capacities are relatively small.

In Taiwan, the sizes of state-owned banks are much larger than private banks, all state-owned banks fall into the dominant group, and most private banks are in the fringe group. If the empirical evidence shows that the pattern of conjectures is in the form of: $\lambda_{s s}+\delta_{s s} m_{i t}>0$, and $\lambda_{p s}+\delta_{p s} m_{i t}<0$ for $i \in S$, we can safely claim therefore that a certain degree of collusiveness exists in Taiwan's banking sector, even if most of the dominant banks are owned by the government. I now insert estimated coefficients into (1) and compute the conjectural elasticity for the mean, $90^{\text {th }}$, and $10^{\text {th }}$ percentile firms, which are listed in Table 2.

On average, a state-owned bank expects the other state-owned banks to increase their output by $0.68 \%$ for every $1 \%$ expansion of their own. The evidence shows that state-owned banks are expected to behave as an implicit or explicit cartel vis-à-vis the other banks in their own groups no less than the way an ordinary private cartel behaves. In essence, state-owned banks fail to act as an internal regulation mechanism to protect and uphold market competition. Secondly, the larger state-owned 
banks anticipate a lesser retaliatory output expansion than the smaller ones. For instance, a $90^{\text {th }}$ percentile state-owned (large) bank with $9 \%$ share of the overall market would expect the other state-owned banks to increase their output by $0.43 \%$ for each $1 \%$ expansion of its own. However, a $10^{\text {th }}$ percentile bank with a market share of $2.33 \%$ would expect the other banks to increase their output by $0.90 \%$. This constitutes a strong deterrent for the output expansion of small state-owned banks.

As to the conjectures of state-owned banks with respect to the reactions of private banks, one can find that the larger state-owned banks behave like von Stackelberg leaders $v i s-\grave{a}$-vis the private banks. For instance, a $90^{\text {th }}$ percentile state-owned bank expects the private banks to contract by $1.18 \%$ for each $1 \%$ expansion of its own. ${ }^{3}$ However, for a $10^{\text {th }}$ percentile bank, its conjecture is quite low and statistically insignificant from 0 . Smaller state-owned banks expect little if any reaction from private banks. The evidence indicates that Taiwan's state-owned banks behave exactly the way NEIO predicts in a dominant cartel model.

Table 2. Estimated Conjectures (unit: \%)

\begin{tabular}{|c|c|c|c|}
\hline & $\begin{array}{c}\text { Mean } \\
\text { bank }\end{array}$ & $\begin{array}{c}90^{\text {th }} \\
\text { percentile } \\
\text { (large) bank }\end{array}$ & $\begin{array}{c}10^{\text {th }} \\
\text { percentile } \\
\text { (small) bank }\end{array}$ \\
\hline \multicolumn{4}{|c|}{ State-owned banks } \\
\hline$\lambda_{s s}+\delta_{s s} m$ & $0.68^{*}$ & $0.43^{*}$ & $0.90^{*}$ \\
& $(0.09)$ & $(0.20)$ & $(0.19)$ \\
\hline$\lambda_{p s}+\delta_{p s} m$ & $-0.56^{*}$ & $-1.18^{*}$ & 0.004 \\
& $(0.21)$ & $(0.37)$ & $(0.005)$ \\
\hline \multirow{3}{*}{$\lambda_{p p}+\delta_{p p} m$} & Private banks & 1.51 \\
\hline$\lambda_{s p}+\delta_{s p} m$ & 0.74 & 0.1310 & $(1.46)$ \\
\hline & $(0.83)$ & $(0.16)$ & -1.07 \\
\hline
\end{tabular}

Notes: The figures in brackets are asymptotic standard errors, which are estimated by the delta method. * denotes that the estimates are significant at the $1 \%$ level.

Among the private banks, most of them are small with respect to market share and would not expect reactions

\footnotetext{
${ }^{3}$ The state-owned bank conjecture of small private banks is negative, provided that the bank has a market share higher than $2.3 \%$.
}

from state-owned banks, except that some large private banks might hold the consensus to coordinate the market behaviors and indeed be concerned about the reactions of state-owned banks. This makes up a typical incomplete cartel, in which large firms cooperate, while the small fringe firms are ignored by dominant firms.

\section{Conclusion}

The empirical evidence reveals that a certain degree of market coordination exists in Taiwan's banking industry and rejects the hypotheses of the second-best literature, even if some banks are owned by the government. The significantly positive conjecture illustrates a state-owned bank's belief that other state-owned banks will respond aggressively to any attempt by it to increase its output. Such a belief leads state-owned banks to less aggressive behaviors, i.e. a smaller output and a higher price. The expectation of an aggressive rival response actually leads to more collusive equilibrium behavior.

\section{References}

Azzam A. and H. Anderson, 2002, Market Power versus Efficiency in Mixed Oligopolies, Working Paper, CAIEP WP002, Department of Agricultural Economics, University of Nebraska.

Barros, F. and L. Modesto, 1999, Portuguese banking sector: a mixed oligopoly?, International Journal of Industrial Organization, 17, pp. 869-886.

Beck, Thorsten, Asli Demirgüc-Kunt, and Ross Levine, 1999, A new database on financial development and structure, Working Paper, World Bank.

Connor, J., 2004, Global cartels redux: The Amino Acid Lysine antitrust litigation, in Kwoka and White eds., The Antitrust Revolution $4^{\text {th }}$ ed., United States: Harper Collins Publishers.

Spiller, P. and E. Favaro, 1984, The effects of entry regulation on oligopolistic interaction: The Uruguayan banking sector, Rand Journal of Economics, 15 (2), 244-254.

Vickers, J. and G. Yarrow, 1991, Economic perspective on privatization, Journal of Economic Perspective, 5, 111-132. 
